\title{
Aktivitas Interaksi Parasosial Penggemar Kepada Idola (Studi Deskriptif Kualitatif pada Wota dan Woti Penggemar JKT48 di Jabodetabek)
}

\author{
Muhammad Rakha Rizky Pratama, Septia Winduwati \\ muhammad.915170206@stu.untar.ac.id, septiaw@fikom.untar.ac.id \\ Fakultas Ilmu Komunikasi Universitas Tarumanagara
}

\begin{abstract}
JKT48 is an idol group originating from Indonesia and produced by Akimoto Yasushi. This research is expected to be able to explain the parasocial interactions that occur between fans and idols. Parasocial interactions are interactions that occur when individuals interact with people who are presented by the media. This research is focused on finding out how the parasocial interaction activities between JKT48 fans Wota and Woti and JKT48 idols. This study uses the concept of communication theory, fandom theory, and parasocial interactions. This research uses a qualitative approach with a collection method by conducting interviews with three informants, study documentation, and literature study. The results in this study are Wota and Woti will feel sad when their idols leave, Wota and Woti limit their relationship with idols only to idols with fans, Wota and Woti make JKT48 as their guide when they behave. None of the three informants in this study was affected pathological.
\end{abstract}

Keywords: Fans, Idols, JKT48, Parasocial Interaction

\begin{abstract}
Abstrak
JKT48 merupakan grup idola yang berasal dari Indonesia dan diproduseri oleh Akimoto Yasushi. Penelitian ini bermaksud menjelaskan interaksi parasosial yang terjadi antara penggemar dan idola. Interaksi parasosial merupakan interaksi yang terjadi ketika individu berinteraksi dengan orang yang dipresentasikan oleh media. Penelitian ini fokus untuk mengetahui bagaimana aktivitas interaksi parasosial antara penggemar JKT48 Wota dan Woti terhadap idola JKT48. Penelitian ini menggunakan konsep teori komunikasi, teori fandom, dan interaksi parasosial. Penelitian ini menggunakan pendekatan kualitatif dengan metode pengumpulan data berupa wawancara tiga informan, studi dokumentasi, dan studi kepustakaan. Hasil dalam penelitian ini adalah Wota dan Woti akan merasa sedih ketika idolanya keluar, Wota dan Woti membatasi hubungannya dengan idola hanya sebatas idola dengan penggemar, Wota dan Woti menjadikan JKT48 sebagai pedoman mereka saat bertingkah laku. Namun penelitian menunjukkan bahwa efek patologis tidak terjadi pada tiga informan.
\end{abstract}

Kata kunci: Idola, Interaksi Parasosial, JKT48, Penggemar

\section{Pendahuluan}

JKT48 merupakan idol group dari Indonesia dan diproduseri oleh Akimoto Yasushi. JKT48 sendiri memiliki saudari group yang paling tua yaitu AKB48. AKB48 merupakan idol group yang diproduseri oleh produser yang sama dengan JKT48 yaitu Akimoto Yasushi dan memulai debutnya di Jepang pada Desember 2005. Konsep AKB48 adalah "idola yang dapat dijumpai", serta AKB48 memiliki sebuah project yaitu penggemar dapat ikut merasakan proses perkembangan dari 
idolanya. AKB48 memiliki sebuah teater sendiri yang terletak di Akihabara, Tokyo. Teater merupakan sebuah tempat untuk para member tampil di depan para penggemarnya.

Member AKB48 semuanya dipilih melalui proses audisi di mana peserta audisi sendiri berasal dari seluruh negeri. Saat ingin merilis sebuah single, AKB48 melakukan seleksi kepada seluruh member, dan member yang terpilih dalam seleksi tersebut dinamakan senbatsu. Senbatsu merupakan member yang terpilih dalam seleksi untuk membawakan lagu single. Nama JKT48 berasal dari sebuah kota di Indonesia yaitu Jakarta. Produser JKT48 yaitu Yasushi Akimoto mengatakan bahwa JKT48 ini diharapkan bisa menjadikan JKT48 sebagai sebuah jembatan persahabatan dengan Jepang didunia permusikan. JKT48 memiliki konsep yang sama dengan saudarinya AKB48 yaitu "idola yang dapat dijumpai". Dengan konsep tersebut, JKT48 memiliki banyak kegiatan yang dilakukan bersama penggemar seperti, teater, handshake festival, 2 shot (berfoto bersama idola), dan official fan club event.

JKT48 memiliki sebuah teater yang terletak di Mall fX Sudirman, Jakarta. Harga tiket teater JKT48 beragam, Rp.60.000 untuk pelajar Rp.120.000 untuk mahasiswa dan pekerja. Selain itu, JKT48 juga membuka official fans club dengan cara membayar Rp.120.000. Penggemar yang mendaftar akan mendapatkan benefit seperti mengikuti event yang tidak bisa diikuti oleh penggemar yang tidak mendaftar official fans club. Penggemar dari JKT48 juga tidak diperbolehkan untuk mengajak member kesukaannya foto bersama. Oleh karena itu, JKT48 membuat event foto bersama member yang biasa disebut 2 Shot, yang biasa dilakukan setelah teater atau pada saat handshake festival. Kegiatan 2 Shot merupakan sebuah kegiatan berupa foto bersama dengan member yang disukai.

Handshake festival merupakan suatu acara yang dibuat oleh JKT48 untuk mempertemukan fans dengan oshi dan fans tersebut dapat mengobrol dengan oshi sambil berjabat tangan selama 10 detik. Oshi merupakan sebutan fans untuk member yang paling disukai. Untuk dapat mengikut event tersebut, fans harus membayar Rp. 35.000 untuk 1 tiket dan 1 tiket tersebut diberi durasi selama 10 detik. Kegiatan 2 shot merupakan sebuah event yang dibuat oleh JKT48 agar fans dapat foto bersama oshi. Kegiatan ini berbayar dan harga untuk kegiatan 2 shoot pada handshake festival yaitu Rp.100.000. Perbedaan kegiatan 2 shoot di teater dan handshake festival yakni pada handshake festival kegiatan 2 shoot memungkinkan fans memilih member untuk berfoto bersama. Sedangkan kegiatan 2 shoot di teater, fans hanya bisa berfoto dengan member yang sedang perform di teater. Kegiatan 2 Shot di teater sebesar Rp 50.000 .

Penggemar atau fans merupakan sekumpulan orang yang sama-sama memiliki minat untuk membentuk sebuah kelompok penggemar. Biasanya fandom dipergunakan penggemar sebagai alat pencarian informasi mengenai idola yang mereka dukung. Selain itu, fandom juga dipergunakan sebagai sebuah wadah untuk penggemar agar dapat melakukan komunikasi dengan individu lain yang mendukung idola yang sama. Penggemar JKT48 memiliki dua penyebutan nama yang berbeda. Perbedaan tersebut dapat dilihat dari jenis kelaminnya yaitu Wota dan Woti. Wota adalah sebuah nama yang dibuat untuk penggemar laki-laki dan Woti adalah sebuah nama yang dibuat untuk penggemar perempuan. Aktivitas yang dilakukan Wota dan Woti dalam mendukung idolanya berbeda-beda, karena penggemar memiliki cara masing-masing dalam mendukung idolanya. Terdapat penggemar yang menyimpan photobook dan menghafal semua chanting dari JKT48. Namun adapula penggemar 
Muhammad Rakha Rizky Pratama, Septia Winduwati: Aktivitas Interaksi Parasosial Penggemar Kepada Idola (Studi Deskriptif Kualitatif pada Wota dan Woti Penggemar JKT48 di Jabodetabek)

yang hanya ingin mengikuti acara-acara JKT48 tanpa membeli photobook ataupun menghafal chant-chant dari JKT48.

Selain itu, member dari JKT48 juga memperlakukan penggemarnya dengan baik. Mereka berusaha untuk menciptakan hubungan yang dekat melalui media sosial maupun tatap muka. Wota dan Woti juga merupakan fandom yang aktif di media sosial terutama di Twitter. Pada hari ulang tahun salah satu member yang penggemar tersebut sukai, penggemar akan menyiapkan tagar atau hashtag di Twitter. Tagar tersebut disebarluaskan agar bisa menjadi trending topic nomor 1 di Twitter. Inilah yang memicu timbulnya suatu perasaan yang lebih intim dari penggemar JKT48 tersebut terhadap idolanya.

Perasaan yang dirasakan oleh penggemar JKT48 tersebut bisa disebut juga sebagai interaksi parasosial. Setyanto, Winduwati dan Utami (2017) menyatakan bahwa interaksi parasosial adalah suatu interaksi yang dilakukan ketika seseorang melakukan interaksi dengan idola yang didukung seolah-olah orang itu nyata. Aktivitas interaksi parasosial yang terjadi antara penggemar JKT48 dengan idola sangat menarik untuk diteliti karena meskipun mereka menggemari idola yang sama tetapi cara mendukung mereka berbeda-beda dan perasaan yang timbul kepada idolanya pun berbeda-beda. Hal itulah yang membuat peneliti tertarik untuk melihat bagaimana interaksi parasosial yang dialami oleh penggemar dari idol group JKT48. Penelitian ini difokuskan pada interaksi parasosial yang terjadi antara Wota dan Woti dengan idola JKT48.

\section{Metode Penelitian}

Penelitian ini menggunakan pendekatan kualitatif. Pendekatan kualitatif dapat memberikan petunjuk untuk kehidupan masyarakat, sejarah, tingkah laku. Penelitian kualitatif memiliki penekanan pada sebuah kualitas data dan tidak menghitung banyaknya data. (Kriyantono, 2012). Perbedaan antara penelitian kualitatif dan penelitian kuantitatif yaitu penelitian kuantitatif berdasarkan data, dan menggunakan teori yang sudah ada untuk memberikan kejelasan dan diakhiri dengan sebuah teori.

Penelitian ini merupakan penelitian studi kasus untuk mendapatkan referensi secara keseluruhan mengenai sebuah sasaran. Dapat diartikan bahwa data yang telah dikumpul dapat dipelajari secara keseluruhan. Peneliti ingin mengetahui lebih dalam mengenai aktivitas interaksi parasosial yang terjadi pada penggemar JKT48 dan dimensi-dimensinya. Metode pengumpulan data pada penelitian ini menggunakan wawancara mendalam. Hal ini bertujuan untuk mencari tahu sudut pandang dari Wota dan Woti mengenai bagaimana aktivitas interaksi parasosial yang terjadi antara Wota maupun Woti dengan idola. Narasumber sudah ditentukan berdasarkan kriteria yakni seorang penggemar JKT48, laki-laki dan perempuan, berusia 20-25 tahun, dan sudah menjadi penggemar JKT48 selama lebih dari 2 tahun.

Narasumber pertama bernama Pristia. Pristia adalah Woti JKT48 berusia 21 tahun, berasal dari kota Tangerang dan merupakan mahasiswi aktif. Pristia mulai tertarik dan mengikuti JKT48 sejak tahun 2013. Narasumber kedua bernama Wildan. Wildan merupakan Wota JKT48 berusia 23 tahun, berasal dari kota Bekasi dan merupakan mahasiswa aktif. Wildan mulai tertarik dan mengikuti JKT48 sejak tahun 2011 pada saat pengumuman pembentukan JKT48 dibuka. Narasumber ketiga bernama Agnez. Agnez merupakan Woti JKT48 berusia 21 tahun, berasal dari Jakarta dan merupakan mahasiswi aktif. Agnez tertarik dan mengikuti JKT48 sejak tahun 2012 pada saat pertama kali JKT48 debut. 
Setelah mendapatkan informan yang sesuai dengan kriteria, selanjutnya peneliti melakukan penyaringan kepada beberapa narasumber yang termasuk dalam kriteria dengan mencari narasumber yang sesuai dengan kriteria yang telah ditetapkan. Teknik analisis data pada penelitian ini menggunakan teknik analisis data model interaktif. Miles dan Huberman menyatakan bahwa teknik analisis data model interaktif terbagi menjadi 4 tahap, yaitu mengumpulkan data, mereduksi data, display data serta memberikan kesimpulan (Herdiansyah, 2010). Pada penelitian ini peneliti menggunakan triangulasi sumber untuk teknik keabsahan data.

\section{Hasil Temuan dan Diskusi}

Penelitian ini dilakukan dengan wawancara kepada tiga orang informan. Hasil temuan dan diskusi ini akan peniliti paparkan menjadi beberapa subpembahasan. Narasumber pertama bernama Pristia. Pristia merupakan Woti JKT48 berusia 21 tahun, berasal dari kota tangerang dan merupakan mahasiswi aktif. Pristia menjelaskan bahwa dirinya mulai tertarik dan mengikuti JKT48 sejak tahun 2013. Narasumber kedua bernama Wildan. Wildan merupakan Wota JKT48 berusia 23 tahun, berasal dari kota Bekasi dan merupakan mahasiswa aktif. Wildan menjelaskan bahwa dirinya mulai tertarik dan mengikuti JKT48 sejak tahun 2011 pada saat pengumuman pembentukan JKT48 dibuka. Narasumber ketiga bernama Agnez. Agnez merupakan Woti JKT48 berusia 21 tahun, berasal dari Jakarta dan merupakan mahasiswi aktif. Agnez menjelaskan bahwa dirinya mulai tertarik dan mengikuti JKT48 sejak tahun 2012 pada saat pertama kali JKT48 debut.

\section{Dimensi Interaksi Parasosial}

Peneliti dari Belanda, Pekka (Setyanto, Winduwati dan Utami, 2017) menemukan lima dimensi yang menggambarkan interaksi parasosial yaitu pertemanan khayalan, mencari teman, empati kepada performer, realitas dari hubungan dan kompetensi performer. Pada dimensi mencari teman, Wota dan Woti cenderung aktif dalam fandom dan mencari teman sesama penggemar JKT48 agar dapat mendukung idola yang sama. Dimensi interaksi parasosial selanjutnya adalah empati kepada performer, penggemar JKT48 baik Wota maupun Woti memiliki rasa empati kepada anggota JKT48. Contohnya ketika salah satu personil JKT48 mengumumkan kelulusan atau keluar dari JKT48, mereka akan merasakan kesedihan terhadap hal tersebut.

\section{Efek Interaksi Parasosial}

Dalam interaksi parasosial memiliki efek-efek seperti sense of companionship, pseudo-friendship, pedoman dalam bertingkah laku, personal identity dan pemirsa patologis (Setyanto, Winduwati dan Utami, 2017). Penggemar JKT48 cenderung melihat JKT48 sebagai idola mereka tidak berharap dapat menjalin hubungan yang lebih. Efek interaksi Parasosial selanjutnya penggemar JKT48 baik Wota dan Woti mereka sama-sama menjadikan JKT48 sebagai pedoman mereka saat bertingkah laku.

Perilaku yang telah dilakukan oleh Wota dan Woti JKT48 untuk idolanya adalah menonton teater, mengikuti event handshake, videocall, menonton koser, dan membeli merchandise idolanya. Alasan penggemar JKT48 masih bertahan untuk mendukung idolanya karena mereka merasa mendapatkan sebuah keterbukaan dari sang idola dan juga mereka merasa mendapatkan penyemangat baru saat menjalani 
aktivitas. Alasan Wota dan Woti mengeluarkan uang yang cukup banyak demi idolanya karena mereka menganggap mengidolai idolanya merupakan sebuah hobi, jadi mereka dapat mengeluarkan uang yang cukup banyak demi menjalani hobinya tersebut.

Selain itu, mereka rela untuk mengeluarkan uang yang cukup banyak karena mereka senang untuk mendukung idolanya dan mereka sadar bahwa untuk mendukung idolanya butuh pengorbanan, jadi mereka rela untuk mengeluarkan uang yang cukup banyak tersebut demi mendukung idolanya.Efek interaksi parasosial selanjutnya yaitu penggemar JKT48 baik Wota maupun Woti sama-sama tidak memiliki rasa hubungan persahabatan dengan JKT48. Ketiga narasumber pada penelitian tidak ada yang merasakan efek patologis. Wota dan Woti sadar bahwa mereka memiliki batasan dan dapat memilih tindakan mana yang boleh untuk ditiru dan mana yang tidak layak untuk ditiru. Wota maupun Woti menjadikan JKT48 sebagai panutan dalam hal-hal positif dan sebagai penggemar mereka berusaha untuk tidak meniru tindakan yang negatif. Dalam penelitian ini dapat dilihat bahwa penggemar JKT48 baik Wota maupun Woti mereka menyukai dan menggemari JKT48 dengan koneksi rasional dan aktif dalam berkomunikasi difandom.

\section{Simpulan}

Penelitian ini menunjukkan terjadinya aktivitas interaksi parasosial. Wota maupun Woti Pada dimensi mencari teman, Wota dan Woti merasa mendapatkan keterbukaan dari sang idola yang membuat mereka merasa menjadi seorang teman dari sang idola. Penggemar JKT48 baik Wota dan Woti mereka sama-sama menjadikan JKT48 sebagai pedoman mereka saat bertingkah laku. Wota dan Woti cenderung menggunakan media sosial seperti Twitter dan Instagram untuk memberikan dukungan dan menyemangati idolanya, Penggemar JKT48 Wota dan Woti membatasi hubungannya dengan idola hanya sebatas idola dengan penggemar. Penggemar JKT48 baik Wota maupun Woti mereka sama-sama tidak memiliki rasa hubungan persahabatan dengan JKT48.

penggemar JKT48 baik Wota maupun Woti sama-sama memiliki rasa empati terhadap anggota JKT48. Pada saat mendukung idolanya, Wota dan Woti Ketiga narasumber pada penelitian tidak ada yang merasakan efek patologis. Wota dan Woti sadar bahwa mereka memiliki batasan dan dapat memilih tindakan mana yang boleh untuk ditiru dan mana yang tidak layak untuk ditiru. Dalam penelitian ini dapat dilihat bahwa penggemar JKT48 baik Wota maupun Woti mereka menyukai dan menggemari JKT48 dengan koneksi rasional dan aktif dalam berkomunikasi difandom.

\section{Ucapan Terima Kasih}

Ucapan terima kasih penulis berikan kepada semua narasumber yang telah bersedia memberikan informasi dan meluangkan waktu kepada peneliti selama proses penelitian ini. Peneliti juga mengucapkan terima kasih kepada Fakultas Ilmu Komunikasi Universitas Tarumanagara. Terima kasih kepada orang tua, teman dan segala pihak yang membantu penulis selama penelitian ini berlangsung. 


\section{Daftar Pustaka}

Abidin, Yunus. (2010). Strategi Membaca Teori dan Pembelajaranya. Bandung: Risqi Press.

Herdiansyah, Haris. (2010). Metodologi Penelitian Kuantitatif. Jakarta: Salemba Humanika.

Kriyantono, Rachmat. (2012). Teknik Praktis Riset Komunikasi. Jakarta: Kencana Pernada Media Group.

Setyanto, Y., Winduwati, S., \& Utami, L. S. S.. (2017). Early Adolescent Behavior on Media Toward Idol Figure (Parasoial Study Preliminary Youth As An Effect of New Media). International Journal of Communication and Media Studies (IJCMS) Vol 7 Issue 2 May-Jun 2017. India: Transstellar Journal Publications \& Research Consultancy Pvt. Ltd. 